Research Article

\title{
An Analysis of the Differences of Marital Adjustment among Educated Career and Non-career Women in Bangladesh
}

\author{
Shammi Akhter \\ Department of Sociology, University of Chittagong, Bangladesh.
}

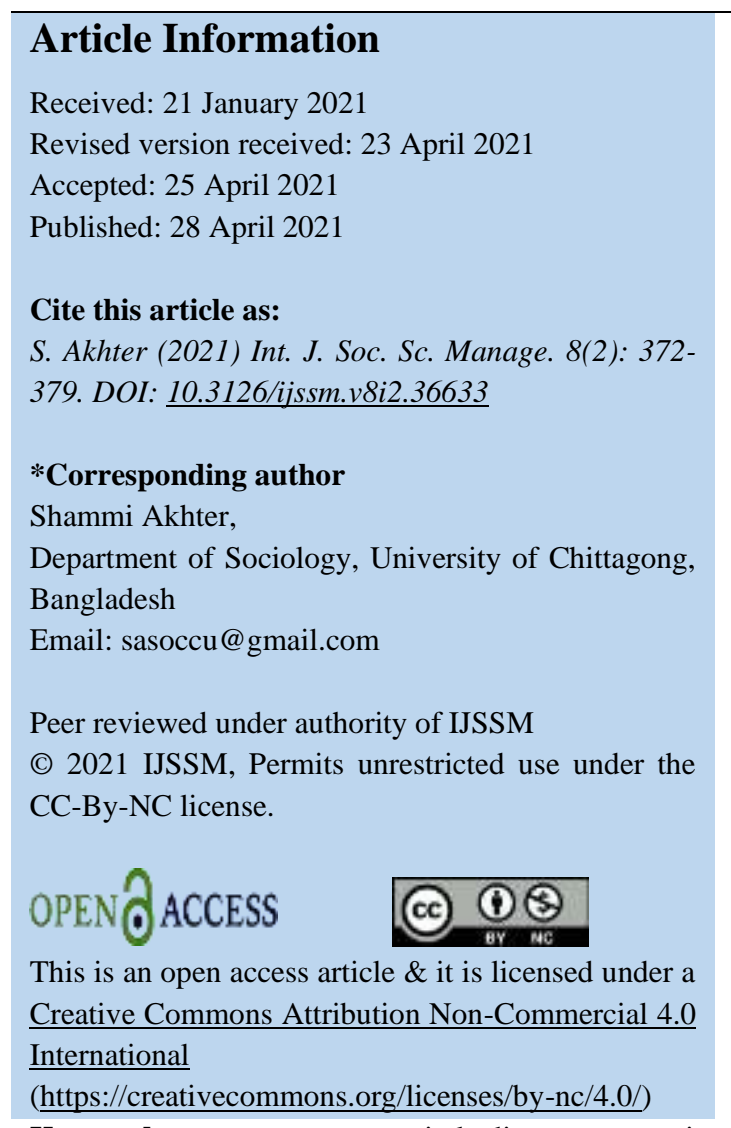

\begin{abstract}
Present study aimed to explore the differences of marital adjustment among educated women in Bangladesh, especially career or dual career married women and non-career or housewives. The study has focused on both qualitative and quantitative approach or mixed method to address the aforesaid issue. Field survey and face to face interview technique was used for data collection. A sample of fifty educated women (twenty-five career and twenty-five non-career women) was selected based on purposive sampling technique and a detailed interview schedule was constructed in this regard. This study revealed that higher educational qualification of husband and wife, increased marital cohesions and harmonies, dissolution and duration of marriage are very important for marital adjustment. Marital adjustment is an important area of research as it promotes emotional stability, intellectual efficiency, and social effectiveness.
\end{abstract}

Keywords: career women; marital adjustment; marriage; non-career women.

\section{Introduction}

The total population of women in Bangladesh is about 80067308 (Bangladesh Demographic profile, 2018). Like many other developing countries, despite having overall vulnerability, women in Bangladesh showed a progressive change towards their participation in formal education and employment market since nineties. The literacy rate of the women in Bangladesh is $69.9 \%$ (2016 est.). Women workforce rate is growing fast in Bangladesh. Female labours force is 1.72 crore, women employment in formal sector is 13 lakhs, women not in labour force is 3.05 crore, women unemployment rate is $5.8 \%$ and labour force participation for women is $36 \%$ compared to $82.5 \%$ for men (The daily star, October 11, 2015).

Marriage and marital adjustment are two of the most commonly uttered words in our quotidian life. Marriage is divine but selecting a partner is an art on which adjustment depends much. Selecting a partner and entering into a 
marital contract are the components of maturational milestone and are considered to be the most important personal achievement. Marriage involves a socially or ritually recognized union or legal contract between spouses establishing rights and obligations between them. It also involves a sense of priority towards commitment with love and responsibility. The ideas of permanence and legitimacy are related to marriage and it spells out the reciprocity of rights and obligation to family members. The general perception is that there is a positive or direct relationship between marriage and happiness and vice-versa. In view of the above, we can also say that the higher level of education attained by husband and wife is likely to ensure a better and stable family life. In aforesaid topic, the term marital adjustment is a universal phenomenon referring to the harmony and cooperation between couples in order to be able to lead a happy life with least frustration, anxiety and feelings of maladjustments and deprivations.

\section{Statement of the Problem}

This article concentrated on the differences of marital adjustment among educated women in Bangladesh, especially career or dual career married women and noncareer or housewives. Working women get frustrated when they cannot give sufficient time to their children and this might become the root cause of marital conflict. Marital adjustment and happiness of family are more dependent on the helping attitude of husband and other family members. So this study wants to find out the distinguishing features and techniques of marital adjustment among educated working and non-working women. This study also tries to explore the relationship between marital satisfaction and age at marriage of women. Education has the inherent capacity to make a person more rational and can help to take necessary decision for the stability of her marital life. Some study showed that full-time working women are happier than fulltime housewives (Ferree ,1976). On the other hand, some study showed that dual-career or full-time employed women feel anxiety due to their double stress to maintain their family. (Aleem and Danish 2008; Gupta and Agarwal 2016). So, this study is an attempt to explore opportunities and impediments of marital adjustment among career and non-career educated women. The present study is an attempt to explore which segments of women are more satisfied in their marital life? Secondly, it is also an attempt to find out their adjustment-techniques with their husbands with a view to establishing a good marital harmony. The findings of the result might be beneficial for the other portions of women in general and this study might expand avenues for further socio-demographic enquiries.

One of the earlier attempts to assess marital adjustment was that of Jessie Bernard who investigated the relationship between adjustment and attitudes. She hypothesized that there were significant differences between the attitudes of adjusted and maladjusted couples. Bernard (1975) defined adjustment as the harmonious interaction between the individual and the world and said marital relationship as a union, there is a tradeoff such that when the success of one partner in imposing a choice means that the other partner must give up his/her preference. They must face the world as a unit (Bernard, 1942). In general, the sex roles of career and non-career women can be ramified into two categories namely the wife staying home and responsible for household chores and child rearing tasks and career spouses where sharing of household tasks based on the principle of equity (Amato et al,1995). Francis (2012) concluded that marriage is for love and love generates happiness where superiority complex is utterly prohibited. They must think themselves complementary to each other.

The concept of 'educated career women' stands for those wives, who upon completion some diploma, certificates or degree working either in some private or government organization (Leslie and Fyans, 1980) and the phrase 'nonworking women' is used for those women who are not gainfully employed and are totally involved in the household jobs (Saxena, 2009). Adjustment plays a vital role in one's continued and peaceful existence all the time in all spheres of life. Marital adjustment is a relative matter and it generally depends upon the conception of marriage and the standards of adjustment prevalent in a particular society at a particular time. Marital adjustment is a state of accommodation and an environment characterized by a tendency in spouses to determine mind-set of happiness and satisfaction with marriage and with one another (Kapur, 1974).

Rani (2013) found that non-working wives face more adjustment problem. Jamabo and Ordu (2012) reported that working class and non-working-class women enjoy equal marital adjustment and they also found that various educational qualifications enhance their communication skills enabling them to address their problems and enhance their reasoning ability and ability to logically arrive at solution of conflict.

From the aforesaid literature review it is revealed the women's (career and non-career) marital life, their anxiety, their self-esteem and the difference their marital adjustment. But what technique or pattern a woman (career and non-career) takes for being able to lead her marital life smoothly were not examined. So, this study would try to explore the existing research gap considering the present trend.

\section{Objectives of the Study}

The main objective of this study is as follows:

*To find out the differences of marital adjustment between educated career and non-career women. 


\section{Research Questions}

The present study has taken into cognizance the following research questions:

1. Are there any differences in marital adjustment between educated career and non-career women?

2. What are their patterns or techniques in marital adjustment?

\section{Methodology}

Marriage, family, marital relationships, relationship with inlaws, marital maladjustment are the most influential concepts of the day and all of us are very interrelated with family life. Education enables women to assume more autonomy or power both in traditional gender-stratified family setting and in more egalitarian ones, giving them greater control over their own lives and stronger voice in matters affecting themselves and their families.

How do socio-cultural norms and institutional education affect a career and a non-career woman's marital life and which way or patterns and which norms they had followed to keep or maintain their marital adjustment? - are the basic questions of present study.

To conduct the research, qualitative and quantitative approach or mixed methods have been used. For the sake of collecting data properly and avoiding incoherence, a structured questionnaire was prepared. To collect all types of information about marital life some questions in quantitative structured (or close-ended) and some questions in qualitative structured (or open-ended) have been incorporated. The Study was conducted in the Chittagong University campus and Chittagong city (GEC and Agrabad). A sample of fifty educated women (twenty-five career and twenty-five non-career women) was selected based on purposive sampling technique and a detailed interview schedule with a checklist were prepared for conducting the field survey and face to face interview technique was used for data collection.

\section{Data Analysis and Findings}

Marriage is an important institution in almost all societies in the world and marital adjustment is an essential element of successful family life. The present study draws from the premise that husbands and wives in acculturating families adapt to the new culture to different extents, in dissimilar modes and, thus, their differences could cause conflict in their joint decision making. Different studies have examined marital adjustment in relation to a score of social, psychological, demographic, cultural, interpersonal and health variables (Gottman 1994). Data were collected on the basis of demographic variables, interaction and marital satisfaction of educated married women (Table $1 \&$ Table 2). The present study tries to reveal that how demographic variables (e.g. age, education, children, duration of marriage, income etc.) impact marital adjustment among career and non-career women. Education is the key to addressing ingrained discrimination and violence against women. According to BBS survey, higher education helps to reduce violence against women in intimate partner relationship. Women's level of education influences her marital quality. Greenstein (1990) stated better or higher education on the part of woman reduces the likelihood of marital dissolution. The dimension of the level of wife and husband's education has drastically changed over the years compared to early decades. The present study revealed that most of the husband's educational qualifications do not show a discrepancy with that of their wives. Since education enhances understanding and both husband and wife attain almost the same level of degree, it defensible to tell that all these components will lead to higher marital adjustment.

On the basis of size there are two types of family in Bangladesh- nuclear family and extended or joint family. Joint type of family system was the tradition of Bengali culture but this system is breaking up because of some important reasons, like- rise of individualism, economic pressure, rural to urban migration, changing status of women; especially female education and outdoor job and higher aspiration of life. The present study found that the number of nuclear family is higher than joint family among both the career and non-career women group in Bangladesh.

Different study revealed that eighty three percent married women (age between 20-39) had arranged marriage (The Daily Star, September 03, 2015) and the present study also found that percentage of arranged marriage of women is bigger than love marriage. There is a slight difference in the pattern of getting marriages between working and nonworking educated women and the respondents disagree with the statements that patterns of marriages have significant impact on marital adjustment.

The present study and previous different study found that the age at first marriage for women in Bangladesh are increasing because of some significant reasons, likeawareness about reproductive health, awareness about consequences of early marriage, impact and implication of marriage related laws, expansion of educational programs activities and increased scope of education, employment and empowerment of women, decrease in socio-religious superstition and prejudice and desire for self-reliance (Samad, 2015). Again, Education can help women to build their family in a planned way and create small family. The present study showed that there is no difference in marital adjustment between career and non-career women in the question of having offspring because both the categories have the same tendency to take offspring. Several studies have claimed to find a U-shaped pattern for marital quality over the marital life. Adjustment tends to be high during the initial stage of marriage and then decline approximately during lifespan and rises in the later years. The marital 
relationship does not exist in a vacuum but it is directly affected by the emotional, physical and psychological issues. (Patrick et al, 2007). The proposed research, in congruence with the aforesaid literature has also explored the case articulately. Age difference between husband and wife is a predictor of marital adjustment. Family income is an influential factor in marital adjustment and according to studies, there are significant difference exists between economic solvency of working and non-working women. Non-working married women have to face more economic problems in their married life as compared to working married women and consequently they face more stress and visibly less adjusted. The matter of fact is that other factors also influence the adjustment process and it is a mix blending of multifarious components.

Quality of life, happiness and well-being of one's life depend on the interaction style among its family members. Within a family arena, members of a family are bounded together by a degree of interdependence. These patterns of interdependence define the nature of relationships, thus a change in one family member result in a change in another family member.

Marriage is not about two persons getting into the wedlock but it is about two families entering into the marriage. In marriage two individuals unite to become one soul but still their previous family that is their parents remains an inseparable part of their new life. Hence in-law relationships are very important determinant of marital adjustment. Conflicts in in-law relationships somehow penetrate into marital relationship and significantly affect marital adjustment. The present study significantly concludes that career women rather than non-working women maintain more persistent in-laws' relationship in their conjugal life and husbands of their both categories women keep a warm and modest relationship of their inlaws.

Table 1: Differences of marital adjustment on the basis of demographic profile of the respondent

\begin{tabular}{|c|c|c|c|c|}
\hline Criterion & $\begin{array}{l}\text { Working } \\
\text { women }\end{array}$ & Percentage & $\begin{array}{l}\text { Non-working } \\
\text { women }\end{array}$ & Percentage \\
\hline $\begin{array}{l}\text { (1) Age } \\
21-30 \\
31-40 \\
41-50\end{array}$ & $\begin{array}{l}05 \\
14 \\
06\end{array}$ & $\begin{array}{l}20 \% \\
56 \% \\
24 \%\end{array}$ & $\begin{array}{l}07 \\
14 \\
04\end{array}$ & $\begin{array}{l}28 \% \\
56 \% \\
16 \%\end{array}$ \\
\hline $\begin{array}{l}\text { (2) Level of education } \\
\text { H.S.C. } \\
\text { B.A. B.S. S, B.S.C. } \\
\text { M.A, M.S. C. } \\
\text { M.B.B.S. } \\
\text { M.Phil } \\
\text { M.Ed. } \\
\text { PhD } \\
\end{array}$ & $\begin{array}{l}00 \\
01 \\
19 \\
01 \\
02 \\
01 \\
01\end{array}$ & $\begin{array}{l}0 \% \\
04 \% \\
76 \% \\
04 \% \\
08 \% \\
04 \% \\
04 \%\end{array}$ & $\begin{array}{l}01 \\
10 \\
14 \\
00 \\
00 \\
00 \\
00\end{array}$ & $\begin{array}{l}04 \% \\
40 \% \\
56 \% \\
0 \% \\
0 \% \\
0 \% \\
0 \%\end{array}$ \\
\hline $\begin{array}{l}\text { (3) Level of husband's education } \\
\text { B.A, B.S.S. } \\
\text { M.Sc, M.A, M.S.S, M.B.A, } \\
\text { M. Com } \\
\text { M.Phil } \\
\text { PhD } \\
\text { M.B.B.S. }\end{array}$ & $\begin{array}{l}03 \\
19 \\
01 \\
01 \\
01\end{array}$ & $\begin{array}{l}12 \% \\
76 \% \\
04 \% \\
04 \% \\
04 \%\end{array}$ & $\begin{array}{l}02 \\
17 \\
02 \\
04 \\
00\end{array}$ & $\begin{array}{l}08 \% \\
68 \% \\
08 \% \\
16 \% \\
0 \%\end{array}$ \\
\hline $\begin{array}{l}\text { (4) Pattern of the family } \\
\text { Nuclear } \\
\text { Joint }\end{array}$ & $\begin{array}{l}17 \\
08\end{array}$ & $\begin{array}{l}68 \% \\
32 \%\end{array}$ & $\begin{array}{l}19 \\
06\end{array}$ & $\begin{array}{l}76 \% \\
24 \%\end{array}$ \\
\hline $\begin{array}{l}\text { (5) Pattern of getting marriage } \\
\text { Love marriage } \\
\text { Arranged marriage } \\
\end{array}$ & $\begin{array}{l}06 \\
19\end{array}$ & $\begin{array}{l}24 \% \\
76 \%\end{array}$ & $\begin{array}{l}03 \\
22\end{array}$ & $\begin{array}{l}12 \% \\
88 \%\end{array}$ \\
\hline $\begin{array}{l}\text { (6) Age of years to get marry } \\
16-20 \\
21-25 \\
26-30 \\
31 \text { and above }\end{array}$ & $\begin{array}{l}03 \\
07 \\
14 \\
01\end{array}$ & $\begin{array}{l}12 \% \\
28 \% \\
56 \% \\
04 \%\end{array}$ & $\begin{array}{l}07 \\
14 \\
04 \\
00\end{array}$ & $\begin{array}{l}28 \% \\
56 \% \\
16 \% \\
0 \%\end{array}$ \\
\hline $\begin{array}{l}\text { (7) No. of offspring } \\
\text { No child } \\
01 \\
02 \\
03 \text { and above }\end{array}$ & $\begin{array}{l}02 \\
10 \\
12 \\
01\end{array}$ & $\begin{array}{l}08 \% \\
40 \% \\
48 \% \\
04 \%\end{array}$ & $\begin{array}{l}02 \\
06 \\
12 \\
05\end{array}$ & $\begin{array}{l}08 \% \\
24 \% \\
48 \% \\
20 \%\end{array}$ \\
\hline
\end{tabular}


Table 1: Differences of marital adjustment on the basis of demographic profile of the respondent

\begin{tabular}{|c|c|c|c|c|}
\hline Criterion & $\begin{array}{l}\text { Working } \\
\text { women }\end{array}$ & Percentage & $\begin{array}{l}\text { Non-working } \\
\text { women }\end{array}$ & Percentage \\
\hline \multicolumn{5}{|l|}{ (8) No. of years in marriage } \\
\hline $2-5$ & 07 & $28 \%$ & 02 & $08 \%$ \\
\hline $6-10$ & 05 & $20 \%$ & 07 & $28 \%$ \\
\hline $11-15$ & 06 & $24 \%$ & 06 & $24 \%$ \\
\hline $16-20$ & 05 & $20 \%$ & 08 & $20 \%$ \\
\hline 21 and above & 02 & $08 \%$ & 02 & $08 \%$ \\
\hline \multicolumn{5}{|l|}{ (9) Difference of age between husband and wife } \\
\hline $0-1$ & 05 & $20 \%$ & 03 & $12 \%$ \\
\hline $2-5$ & 11 & $44 \%$ & 05 & $20 \%$ \\
\hline $6-10$ & 06 & $24 \%$ & 13 & $52 \%$ \\
\hline $11-15$ & 03 & $12 \%$ & 02 & $08 \%$ \\
\hline $16-20$ & 00 & $0 \%$ & 02 & $08 \%$ \\
\hline \multicolumn{5}{|l|}{ (10) Income of the family (in taka) } \\
\hline $30000-40000$ & 02 & $08 \%$ & 07 & $28 \%$ \\
\hline $41000-60000$ & 05 & $20 \%$ & 10 & $40 \%$ \\
\hline 61000and above & 18 & $72 \%$ & 08 & $32 \%$ \\
\hline Total & 25 & $100 \%$ & 25 & $100 \%$ \\
\hline
\end{tabular}

Source: Field level survey

Table 2: Differences of marital adjustment on the basis of interaction

\begin{tabular}{|c|c|c|c|c|}
\hline 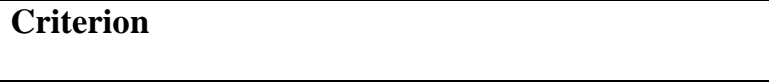 & $\begin{array}{l}\text { Working } \\
\text { women }\end{array}$ & Percentage & $\begin{array}{l}\text { Non-working } \\
\text { women }\end{array}$ & Percentage \\
\hline $\begin{array}{l}\text { 1. Relationship with in-laws and respondents } \\
\text { Normal } \\
\text { Good } \\
\text { Very good }\end{array}$ & $\begin{array}{l}04 \\
16 \\
05\end{array}$ & $\begin{array}{l}16 \% \\
64 \% \\
20 \%\end{array}$ & $\begin{array}{l}02 \\
18 \\
05\end{array}$ & $\begin{array}{l}08 \% \\
72 \% \\
20 \%\end{array}$ \\
\hline $\begin{array}{l}\text { 2. Respondent's husband relationship with in-laws } \\
\text { Very good } \\
\text { Good } \\
\text { Bad } \\
\text { Normal }\end{array}$ & $\begin{array}{l}05 \\
19 \\
00 \\
01\end{array}$ & $\begin{array}{l}20 \% \\
76 \% \\
0 \% \\
04 \%\end{array}$ & $\begin{array}{l}04 \\
16 \\
01 \\
04\end{array}$ & $\begin{array}{l}16 \% \\
64 \% \\
04 \% \\
16 \%\end{array}$ \\
\hline $\begin{array}{l}\text { 3. Misbehaving of the husband } \\
\text { Yes } \\
\text { No }\end{array}$ & $\begin{array}{l}05 \\
20\end{array}$ & $\begin{array}{l}20 \% \\
80 \%\end{array}$ & $\begin{array}{l}06 \\
19\end{array}$ & $\begin{array}{l}24 \% \\
76 \%\end{array}$ \\
\hline $\begin{array}{l}\text { 4. Husband's nagging } \\
\text { Yes } \\
\text { No } \\
\text { Sometimes }\end{array}$ & $\begin{array}{l}07 \\
12 \\
06\end{array}$ & $\begin{array}{l}28 \% \\
48 \% \\
24 \%\end{array}$ & $\begin{array}{l}04 \\
18 \\
03\end{array}$ & $\begin{array}{l}16 \% \\
72 \% \\
12 \% \\
\end{array}$ \\
\hline $\begin{array}{l}\text { 5. Family expenditure } \\
\text { Yes } \\
\text { No }\end{array}$ & $\begin{array}{l}17 \\
08 \\
\end{array}$ & $\begin{array}{l}68 \% \\
32 \% \\
\end{array}$ & $\begin{array}{l}21 \\
04 \\
\end{array}$ & $\begin{array}{l}84 \% \\
16 \% \\
\end{array}$ \\
\hline $\begin{array}{l}\text { 6. Offering cooperation } \\
\text { Yes } \\
\text { No } \\
\text { Sometimes }\end{array}$ & $\begin{array}{l}19 \\
04 \\
02\end{array}$ & $\begin{array}{l}76 \% \\
16 \% \\
08 \%\end{array}$ & $\begin{array}{l}21 \\
01 \\
03\end{array}$ & $\begin{array}{l}84 \% \\
04 \% \\
12 \% \\
\end{array}$ \\
\hline $\begin{array}{l}\text { 7. Engage in outside matters } \\
\text { Yes } \\
\text { No } \\
\text { Sometimes } \\
\end{array}$ & $\begin{array}{l}21 \\
01 \\
03 \\
\end{array}$ & $\begin{array}{l}84 \% \\
04 \% \\
03 \% \\
\end{array}$ & $\begin{array}{l}21 \\
01 \\
03 \\
\end{array}$ & $\begin{array}{l}84 \% \\
04 \% \\
12 \% \\
\end{array}$ \\
\hline $\begin{array}{l}\text { 8. Prefer in leisure time } \\
\text { Similarities } \\
\text { Oppose }\end{array}$ & $\begin{array}{l}11 \\
14 \\
\end{array}$ & $\begin{array}{l}44 \% \\
56 \% \\
\end{array}$ & $\begin{array}{l}19 \\
06 \\
\end{array}$ & $\begin{array}{l}76 \% \\
24 \% \\
\end{array}$ \\
\hline Total & 25 & 100 & 25 & 100 \\
\hline
\end{tabular}

Source: Field level survey 
Physical violence also is closely linked with marital adjustment. According to the daily 'Prothom Alo' report, "80\% married women in Bangladesh are to face violence in their marital life" (October 3, 2016). Globally, one in every three women and girls experience physical or sexual violence in their lifetime, most frequently by an intimate partner (UN report). According to BBS report 2013, higher education helps to reduce violence against women in intimate partner relationship. The present study also revealed that one in every four married women face misbehave from their intimate partner, but this type of misbehave not more than rough behave and violence was not present there. Nagging distorts smoothness of conjugal life and must be avoided to lead a hale and hearty conjugal life. The Table 3 shows that husband's nagging is found to be more among working wives than non-working wives and this explores the fact that career women are less inclined to discuss expenditure related issues because of their economic independence while the discussion regarding this issue among non-career women seems to be higher to some extent. The present study enunciates that the non-working women get little more cooperation, encouragement and emotional support from husband than those of working women. Working women are economically solvent and they think anything independently. But non-working women are dependent, especially economically on their husband. In the matter of showing attitude towards outside affairs, about $84 \%$ working and non-working women replied that they had a wonderful understanding not only on family matters but also on other affairs, such as to attend in birthday parties or wedding ceremony, to give financial support to relatives or outsiders. The present study proves that mental cohesion or similarity of two universes (husband-wife) will lead to the marital cohesion and happiness. In the question of preference in leisure activity, the non-working women responded more positively than working women. The study unveils that the non-working women and their husband enjoy their leisure together than that of working women. Sometimes they (working women) blame each other for their annoying and drudgery life.

It is admitted on all hands that there are some important factors behind a marital success or failure. The integration of couples in a union merges two personalities and they act as a complement for each other in order to bring mutual satisfaction in quotidian life.

The present study shows that more working women than that of non-working women opined ever wish better to be married. Working women have to handle tremendous pressure of household management and corporate hassle. The ambitious women always want advantageous opportunity for career development, but this double pressure retard their career and finding no other way out they blame their marital life. Percentage of never married women has increased more than that of men. It has mounted up from only $10.55 \%$ in 1961 to 41.6 percent in 2011 (BBS, 2015).

Table 3: Differences of marital adjustment on the basis of marital satisfaction

\begin{tabular}{|c|c|c|c|c|}
\hline Criterion & Working & Percentage & Non-working & Percentage \\
\hline \multicolumn{5}{|c|}{ 1. Ever wish better to be married } \\
\hline Yes & 10 & $40 \%$ & 07 & $28 \%$ \\
\hline No & 15 & $60 \%$ & 18 & $72 \%$ \\
\hline \multicolumn{5}{|c|}{ 2. Measuring the marital satisfaction } \\
\hline Marry the same person & 19 & $76 \%$ & 16 & $64 \%$ \\
\hline Marry a different person & 00 & $0 \%$ & 00 & $0 \%$ \\
\hline Not marry at all & 06 & $24 \%$ & 09 & $36 \%$ \\
\hline \multicolumn{5}{|l|}{ 3.Confide the mate } \\
\hline Yes & 24 & $96 \%$ & 25 & $100 \%$ \\
\hline No & 01 & $04 \%$ & 00 & $00 \%$ \\
\hline \multicolumn{5}{|l|}{ 4. Satisfaction in married life } \\
\hline Highly satisfied & 03 & $12 \%$ & 10 & $40 \%$ \\
\hline Moderate satisfied & 20 & $80 \%$ & 15 & $60 \%$ \\
\hline Low satisfied & 02 & $08 \%$ & 00 & $0 \%$ \\
\hline Total & 25 & 100 & 25 & 100 \\
\hline
\end{tabular}

Source: Field level survey 


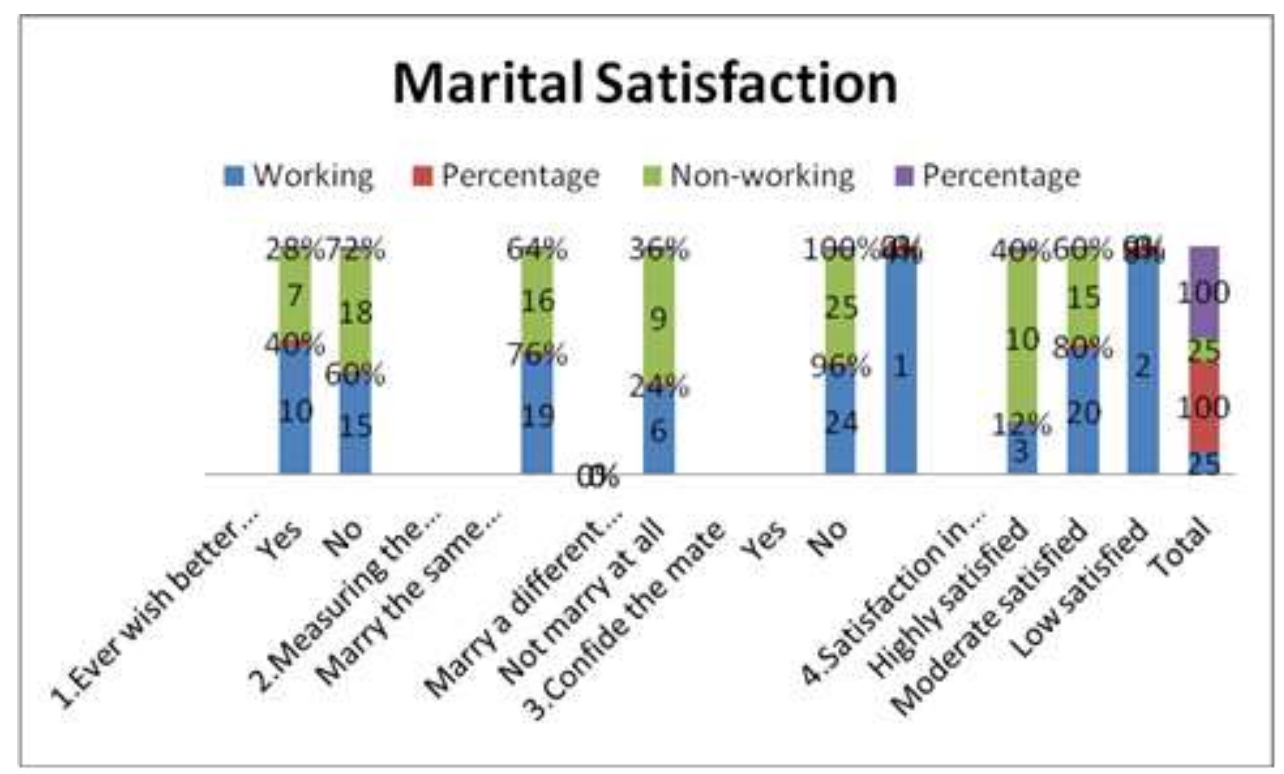

Fig. 1: Differences of marital adjustment on the basis of marital satisfaction

The Fig. 1 shows that about $76 \%$ working and $64 \%$ nonworking wives were happy to marry the same person (the present husband), if they get a chance to restart, because they know their partner's attitudes and emotion very articulately. The two categories of women believe that marital adjustment is also a lifelong commitment and continuous sacrifice for every couple. A spouse who is open to all issue for one's marital partner signifies that he/she is happy with his/her relationship.

Marital satisfaction means that the couples have the feelings of comport, enjoyment and acceptance in all spheres of their marriage life. It is considered an important element in the continuity of their marriage. In the case of highly satisfaction in marriage, working women are less satisfied than non-working women, because of their extra pressure or double burden. None of non-working women only but $08 \%$ working women are lowly satisfied in their wedlock. Again, more $(80 \%)$ working women than nonworking $(60 \%)$ women are moderate satisfied in their marital state.

This research is to find out the differences of marital adjustment between working and non-working women and create some interesting findings that are mentioned below:

(a) Higher educational qualification of husband and wife increase marital cohesions and harmonies and decrease domestic violence and dissolution.

(b) Non-career women and their husbands enjoy more leisure time than career women and they (working women) blame each other for their annoying and drudgery life.

(c) Husbands of both career and non-career women are very sympathize and cooperative.

(d) Duration of marriage is very important for marital adjustment. (e) If husband gets a handsome amount of income, then wife's job is inconsequential in maintaining marital stability.

(f) Both career and non-career women enjoy most the nuclear type of family system.

(g) Women of both categories opined that wedlock is not only a lifelong commitment but also a continuous sacrifice for every marital union.

\section{Conclusion}

This research is undertaken to investigate the marital adjustment among educated women (working or career and non-working or non-career women) in Bangladesh. The patterns and tendencies of marital satisfaction is determined by a plethora of demographic and socio-structural factors.

Education enlightens man in norms, behavior, attitude, understanding and rational judgment. The study reveals some patterns and techniques so that educated women keep or maintain their marital adjustment. Compromise and patience, keeping temper in control, avoid doubting, nagging and misunderstanding; sacrificing, cooperating and sharing, increasing mutual understanding; respecting mutual interests; keeping trust and confidence and good relationship with in-laws are some of the techniques that are pertaining to career women explored in this study. The techniques in marital adjustment of non-career women are: sacrifice in every sector; keep patience and cooperation; mutual trust, confidence and respect; adjustment capabilityeither financial or familial; avoid doubting, nagging and misunderstanding; respect mutual interest; cooperation and discussion in private and outside matters.

\section{References}

Aleem S and Danish L (2008) Marital Satisfaction and Anxiety among single and Dual Career Women. Journal of the 
Indian Academy of Applied Psychology, 34(Special Issue): 141-144.

Amato PR, Loomis LS \& Booth A (1995) Parental divorce, marital conflict, and offspring well-being during early adulthood. Social Forces, 73(3): 895-915. https://doi.org/10.2307/2580551

Bernard J (1942) American Family Behavior. New York: Harper \& Brothers.

Bernard J (1975) The Future of Motherhood New York: Penguin Books.

Ferree MM (1976) Working class jobs: Paid work and housework as sources of satisfaction. Social Problems 23(April): 431441.

Francis K. F (2012) A Comparative Study on The Marital Quality of Couple with and Without Pre-Marriage Education. School of Social Work, Marian College Kuttikkanam.

Gottman J (1994) Why Marriages Succeed or Fail: What You Can Learn from the Breakthrough Research to Make Your Marriage Last. New York: Simon \& Schuster. ISBN 9780-671-86748-5.

Greenstein TN (1990) Marital Disruption and the Employment of Married Women. Journal of Marriage and the Family 52: 657-676.
Halim MA (1995) Women's Crisis Within Family in Bangladesh. City Art Press 173, Fakirapool, Dhaka.

Leslie J and Fyans jr (1980) Women's Achievement and Career Motivation: Their Risk Taking Patterns, Home-career Conflict, Sex Role and Orientation, Fear or Succes and self-control. Achievement Motivation Recent Trends in Theory and Research, Springer science + Business Media, New York.

Patrick S, Sells JN, Giordano FG \& Tollerud TR (2007) Intimacy, differentiation, and personality variables as predictors of marital satisfaction. The Family Journal 15(4): 359-367. https://doi.org/10.1177/1066480707303754

Rani R (2013) Marital Adjustment Problems of Working and Nonworking Women in Contrast of Their Husband . International Journal for Research in Education 2(7): 2134.

Samad Y (2010) Forced Marriage among men: An unrecognized problem. Critical Social Policy 30(2): 189-207.

Saxena P (2009) A Comparative Study of Frustration among Working and Non-working Women. International Research Journal 2(5): 446-448. 